\title{
El catálogo general del patrimonio histórico andaluz en la campiña cordobesa
}

\begin{abstract}
En la campiña cordobesa, conformada por 26 municipios de los cuales seis están afectados parcialmente y 20 totalmente, podemos encontrar 189 bienes que se encuentran incluidos en el Catálogo General del Patrimonio Histórico Andaluz (CGPHA). Si dichos bienes los clasificamos por la figura legal que les da protección, nos encontramos que, frente a los 68 Bienes de Interés Cultural, la gran mayoria son de Catalogación General (121) y la tipologia juridica más usada para su inscripción en el CGPHA es la de Zona Arqueológica.
\end{abstract}

Por Resolución de 11 de diciembre de 2003 de la Dirección General de Bienes Culturales se inscriben, colectivamente, con carácter genérico', 138 yacimientos arqueológicos de varios términos municipales en los que se incluyen tres de la campiña cordobesa: Nueva Carteya (25), Cañete de las Torres (53) y Bujalance (27), sumando un total de 105 yacimientos de los bienes protegidos en este expediente. La mayor parte de los yacimientos aquí catalogados se corresponden con pequeños y medianos asentamientos de carácter rural de época romana o medieval. Algunos de ellos tienen un origen ibérico o incluso se pueden remontar al Calcolítico o a la Edad del Bronce. También se reconocen diversos bienes relacionados con la ingeniería hidráulica romana; el más importante es el constituido por diversos tramos de un acueducto romano y varias cisternas, ubicados en el término municipal de Nueva Carteya. Hay que resaltar también algunos asentamientos amurallados protohistóricos que mantienen importantes estructuras emergentes, como muestra de la arquitectura militar.
Caracteristico de este territorio, que se extiende entre el valle del Guadalquivir y las sierras Subbéticas, es el relieve ondulado en el que sobresalen algunos cerros que, a lo largo de la historia, los diferentes pobladores han utilizado dejando su huella ocupacional, destacando las fortificaciones de época medieval. En el Catálogo General del Patrimonio Histórico Andaluz tenemos 36 Bienes de Interés Cultural, tipologia Monumento, pertenecientes a la arquitectura militar en esta zona. El Castillo de Montemayor, construido en el s. XIV, constituye uno de los más brillantes ejemplos de este patrimonio arquitectónico en la provincia de Córdoba.

La nueva Ley 14/2007, de 26 de noviembre, de Patrimonio Histórico de Andalucia, en su disposición adicional sexta, apartado 2, enuncia: "Los bienes inmuebles del Patrimonio Histórico Andaluz y los elementos de los mismos de piedra, yeso, madera, forja, fundición, cerámica, azulejería y vidrio en los términos del artículo 2 de esta Ley que se encuentren en posesión de la Administración de la Junta de Andalucia, las entidades locales y las Universidades quedan inscritos en el Catálogo General del Patrimonio Histórico Andaluz como bienes de catalogación general". El Servicio de Protección del Patrimonio Histórico, acogiéndose a esta novedosa y ágil protección de bienes, ha realizado un expediente de Catalogación General denominado Pósitos y Tercias de la provincia de Córdoba de propiedad municipal. En dicho expediente se han incluido 16 bienes, de los cuales 7 se encuentran en la campiña cordobesa.
También habría que destacar la protección de "bienes patrimoniales" de tipología diferente a las que habitualmente la Dirección General de Bienes Culturales incluia en el CGPHA a través de sus expedientes de protección. Este es el caso del Patrimonio Arqueológico Subacuático, que mediante el Decreto 285/2009 de 23 de junio de 2009 denominado 56 Bienes sitos en las aguas continentales e interiores de Andaluciá, mar territorial y plataforma continental ribereña al territorio andaluz protegió como Bien de Interés Cultural con la tipologia de Zona Arqueológica, 56 bienes subacuáticos, algunos situados en el interior andaluz como es el caso de Las Mestas, ubicado en Aguilar de la Frontera, dentro de la campiña cordobesa.

El Catálogo General del Patrimonio Histórico Andaluz está abierto a la consulta pública en la página web de la Consejeria de Cultura, www.juntadeandalucia.es/ cultura/, dentro del área de Bienes Culturales.

\section{Alfonso Montejo Ráez Olga Viñuales Meléndez \\ Servicio de Protección del Patrimonio Histórico Dirección General de Bienes Culturales}

\section{Nota}

${ }^{1}$ La nueva Ley 14/2007, de 26 de noviembre, de Patrimonio Histórico de Andalucia, en su disposición adicional segunda, apartado 1, enuncia que "Los bienes inscritos con carácter genérico en el Catálogo General del Patrimonio Histórico Andaluz con anterioridad a la entrada en vigor de la presente Ley tendrán la consideración de bienes de catalogación general".

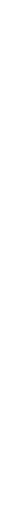

Viñedos de Montilla. Foto: Juan Carlos Cazalla, IAPH 

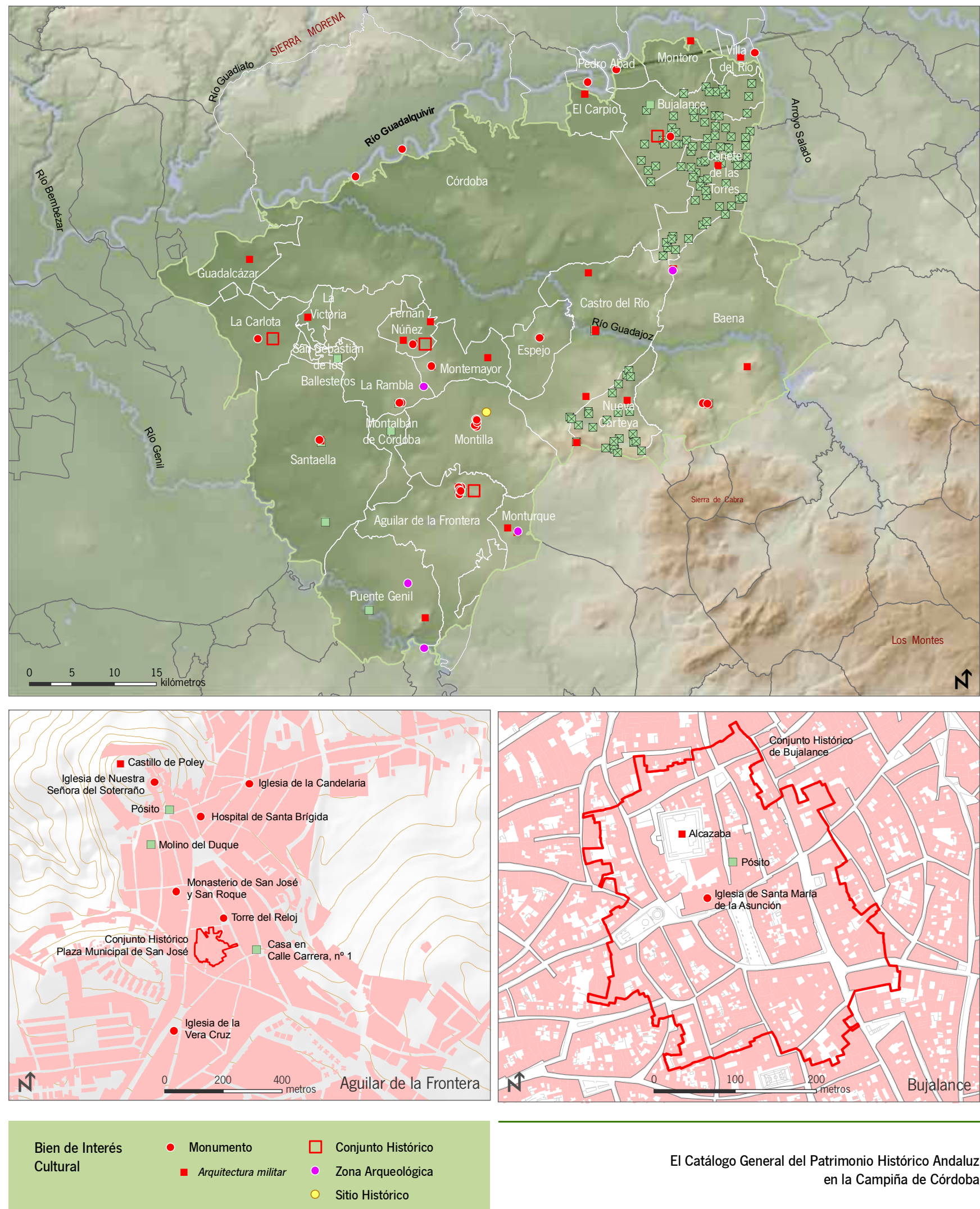

El Catálogo General del Patrimonio Histórico Andaluz en la Campiña de Córdoba

Bien de Catalogación General $\square$

Yacimientos arqueológicos (Resolución 11/12/2003) $\quad \bowtie$

Cartografia base: Datos Espaciales de Andalucia 1:100.000 (2009), Modelo Digital del Terreno de Andalucia (2005), Mapa Topográfico de Andalucia 1:10.000 vectorial (2002), Instituto de Cartografia de Andalucia, y Cartografia Catastral vectorial, Ministerio de Economía y Hacienda (2005) 